\title{
FOOD INTAKE, GROWTH, FOOD CONVERSION, AND BODY COMPOSITION OF CATFISH EXPOSED TO DIFFERENT SALINITIES
}

\author{
S. ARUNACHALAM and S. RAVICHANDRA REDDY \\ Department of Zoology, Bangalore University, Bangalore 560001 (India)
}

(Received 12 June 1978; revised 23 October 1978)

\begin{abstract}
Arunachalam, S. and Reddy, S.R., 1979. Food intake, growth, food conversion, and body composition of catfish exposed to different salinities. Aquaculture, 16:163-171.
\end{abstract}

The effects of different salinities $(0,2,4,6$ and $10 \%$ ) on food intake, growth, food conversion, and body composition of the fresh water catfish Mystus vittatus (Bloch) were studied. Under a restricted feeding schedule daily intake of food was found to be salinity dependent. Fish reared in $10 \%$ consumed more Tubifex tubifex, converted less efficiently and displayed poor growth as compared to individuals reared in fresh water. Fish flesh pro* duction decreased from $483 \mathrm{~g}$ (fresh water) to $177 \mathrm{~g}(10 \%$ salinity) as the salinity was increased. Water content of the fish was found to decrease with increase in salinity, while maximum ash $(25.56 \%$ ) and fat $(42.25 \%)$ were exhibited by fish reared in $10 \%$ salinity.

\section{INTRODUCTION}

It is a well established fact that an organism and its environment cannot be separated and that an organism reacts to its total environment rather than to a single factor (Al Dahan and Bhatti, 1977). A single factor like salinity is found to influence the metabolism of fish (Canagaratnam, 1959; Otto, 1971; Brockson and Cole, 1972; Raghuraman, 1973; De Silva and Perera, 1976). Kinne (1962) demonstrated that growth and food conversion efficiency in fish are valuable indicators of functional adaptation to salinity. Data on the metabolic rates of fish at different salinities are essential for comparative purposes in assessing the effects of sublethal stresses caused by extremes of salinity and low oxygen levels (Hettler, 1976). The present paper details the influence of salinity on food conversion, flesh production and body composition of Mystus vittatus (Bloch).

$M$. vittatus, an indigenous predatory siluroid fish (Moitra, 1956) is abundant in natural and artificial freshwater habitats of South India. Its occurrence, distribution (Muddanna, 1971) and biology (Qayyam and Qasim, 1961) have been studied. The fish is found to be hardy and to feed on algae, crustaceans, insect larvae, oligochaete worms, cladocerans and small fish in its natural habitat (Moitra, 1956; Haffef and Qasim, 1960; Arunachalam, 1978b). 


\section{MATERIAL AND METHODS}

For the present work, juvenile Mystus vittatus ranging in weight from 1.605 to $2.160 \mathrm{~g}$ were selected from the Agaram tank (near Bangalore) and used for the feeding experiments. The experimental fish were reared at five salinities $(0,2,4,6$ and $10 \%)$. At each salinity, three experimental fish were reared in aquaria containing 51 of water. The required salinities were made up by adding common salt to fresh water and the water was aerated for $10 \mathrm{~h} / \mathrm{day}$. The fish were fed ad libitum on the oligochaete worm Tubifex tubifex for $4 \mathrm{~h} /$ day. The feeding was thus continued for 30 days. The fish were then sacrificed in order to study the food intake, growth and body composition. At the beginning of each experiment, a group of individuals was sacrificed for measurement of initial weights and composition.

All chemical analyses were made on material dried to constant weight in a hot-air oven at $95^{\circ} \mathrm{C}$. Fat was estimated as the difference between dry weight $(40 \mathrm{mg})$ and fat free weight of the sample determined after extraction with chloroform-methanol mixture $(2: 1)$ in a soxhlet apparatus. The extraction was run for $20 \mathrm{~h}$, the time recommended by the Association of Official Agricultural Chemists (1950). Ash was determined by incineration of the dried sample (50 $\mathrm{mg}$ ) at $560^{\circ} \mathrm{C}$ for $5 \mathrm{~h}$ (Paine, 1964).

\section{TABLE I}

Effect of salinity on the different metabolic parameters of Mystus vittatus. Values in the fifth, seventh and eighth columns represent the average performance of three individuals

\begin{tabular}{|c|c|c|c|c|c|c|c|}
\hline $\begin{array}{l}\text { Salinity } \\
(\%)\end{array}$ & $\begin{array}{l}\text { Serial } \\
\text { No. }\end{array}$ & $\begin{array}{l}\text { Initial } \\
\text { biomass } \\
\text { (g) }\end{array}$ & $\begin{array}{l}\text { Total food } \\
\text { consumed } \\
\text { (g) }\end{array}$ & $\begin{array}{l}\text { Daily intake } \\
(\mathrm{mg} / \text { fish·day })\end{array}$ & $\begin{array}{l}\text { Yield } \\
\text { (g) }\end{array}$ & $\begin{array}{l}\text { Growth } \\
\text { (mg/fish- } \\
\text { day) }\end{array}$ & $\begin{array}{l}\text { Conversion } \\
\text { efficiency } \\
\left(K_{1}, \%\right)\end{array}$ \\
\hline 0 & $\begin{array}{l}1 \\
2 \\
3\end{array}$ & $\begin{array}{l}1.936 \\
1.085 \\
1.900\end{array}$ & $\begin{array}{l}3.732 \\
2.839 \\
3.485\end{array}$ & 17.84 & $\begin{array}{l}2.532 \\
1.418 \\
2.396\end{array}$ & 2.71 & 15.10 \\
\hline 2 & $\begin{array}{l}1 \\
2 \\
3\end{array}$ & $\begin{array}{l}1.990 \\
1.340 \\
1.650\end{array}$ & $\begin{array}{l}3.869 \\
3.056 \\
3.258\end{array}$ & 17.92 & $\begin{array}{l}2.485 \\
1.697 \\
2.016\end{array}$ & 2.63 & 14.68 \\
\hline 4 & $\begin{array}{l}1 \\
2 \\
3\end{array}$ & $\begin{array}{l}2.220 \\
2.110 \\
2.150\end{array}$ & $\begin{array}{l}4.744 \\
4.925 \\
4.835\end{array}$ & 22.80 & $\begin{array}{l}2.600 \\
2.751 \\
2.675\end{array}$ & 2.39 & 10.10 \\
\hline 6 & $\begin{array}{l}1 \\
2 \\
3\end{array}$ & $\begin{array}{l}1.695 \\
1.615 \\
1.625\end{array}$ & $\begin{array}{l}4.676 \\
4.402 \\
4.302\end{array}$ & 23.19 & $\begin{array}{l}2.045 \\
1.973 \\
1.896\end{array}$ & 1.96 & 8.58 \\
\hline 10 & $\begin{array}{l}1 \\
2 \\
3\end{array}$ & $\begin{array}{l}1.605 \\
1.410 \\
1.800\end{array}$ & $\begin{array}{l}4.438 \\
4.207 \\
4.688\end{array}$ & 23.64 & $\begin{array}{l}1.786 \\
1.506 \\
2.065\end{array}$ & 1.13 & 3.07 \\
\hline
\end{tabular}




\section{RESULTS}

\section{Food intake}

The data in Table I indicate that at $24^{\circ} \mathrm{C}$, maximum food intake (23.64 \pm $1.287 \mathrm{mg}$ dry food/fish - day) was exhibited by fish reared at the highest salinity level $(10 \%)$. During the present study, there appeared to be an increase in food intake as the salinity increased from fresh water $(17.84 \pm 2.445 \mathrm{mg}$ dry food/fish-day) to $10 \%$ (23.64 mg dry food/fish -day).

The feeding rate, expressed as $\mathrm{mg}$ dry food/g live fish-day, of $M$. vittatus at the tested salinities are presented in Fig.1. The value increased from 10.83 $\mathrm{mg} / \mathrm{g}$ live fish day in fresh water to $16.35 \mathrm{mg} / \mathrm{g}$ live fish.day at a salinity of $10 \%$, confirming that food intake is affected by salinity.

\section{Growth}

Maximum growth $(2.71 \mathrm{mg} /$ fish $\cdot$ day, Table I) was displayed by individuals reared in fresh water and as the salinity was increased, growth decreased and the least value ( $1.13 \mathrm{mg} /$ fish - day) was observed at $10 \%$. As seen from Fig.1, growth rate decreased from $1.65 \mathrm{mg} / \mathrm{g}$ live fish - day (fresh water) to $0.73 \mathrm{mg} / \mathrm{g}$ live fish - day $(10 \%)$.

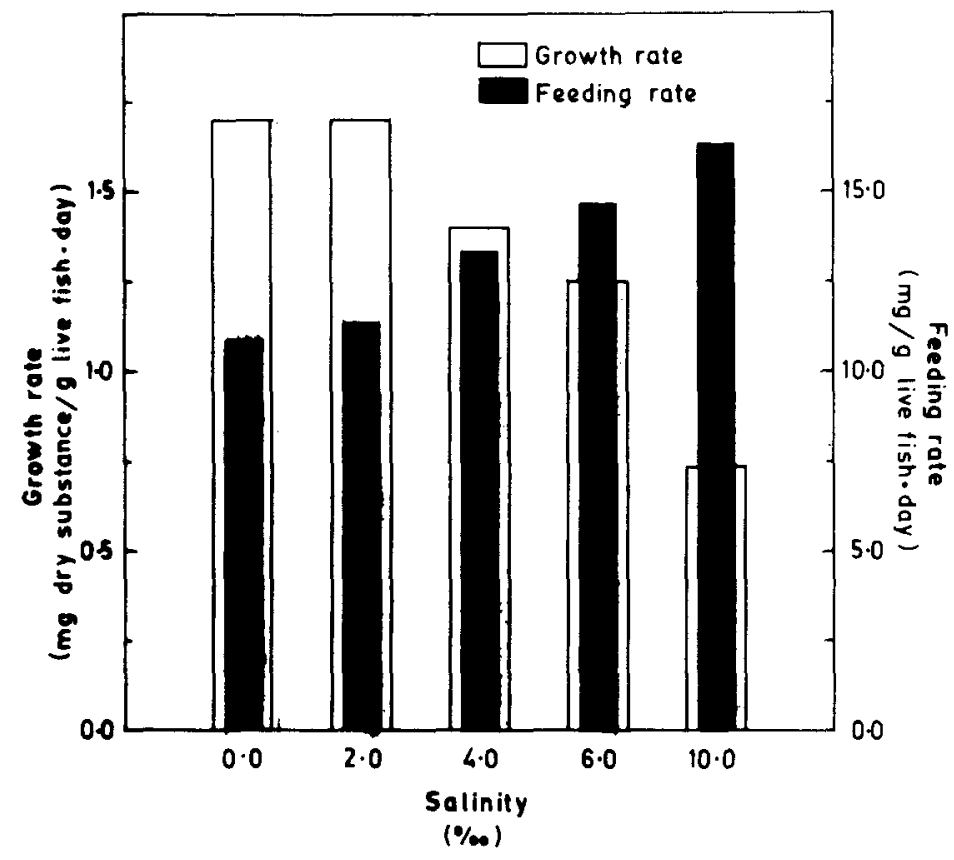

Fig.1. Effect of salinity on the feeding ( $\mathrm{mg}$ dry food/g live fish.day) and growth rates (mg dry substance/g live fish-day) of Mystus vittatus. 


\section{Food conversion}

The conversion efficiency $\left(K_{1}\right)$ has been defined in this paper as the percent of dry food material that is converted into fish flesh and was calculated as follows:

$$
K_{1}=\frac{\text { Growth }(\mathrm{mg}) / \text { day }}{\text { Food intake }(\mathrm{mg}) / \text { day }} \times 100
$$

Fish reared in fresh water not only consumed less food but exhibited the best food conversion efficiency (15.10\%, Table I). The value decreased to $3.07 \%$ when salinity was increased to $10 \%$.

\section{Specific growth rate and flesh production}

In the present study, the specific growth rate (g/day) was calculated using the method described by Kosi Onodera (1962). In Table I, it is shown that a fish biomass (fresh water) of $1.936 \mathrm{~g}$ can yield $2.532 \mathrm{~g}$ at the end of the 30day feeding period. Hence, the total increment amounts to $0.596 \mathrm{~g}$. Therefore, in 30 days the specific growth rate calculated is $0.596 / 1.936 / 30=0.0103$ which is equivalent to $10.3 \mathrm{mg} /$ day. The total amount of food given was $3.732 \mathrm{~g}$ which is equivalent to $3.732 / 1.936 / 30=0.0641 \mathrm{~g} /$ day. Therefore, a daily ration of fish food equivalent to $6.41 \%$ of the initial biomass produced a daily weight increment of fish flesh equivalent to $0.0103 / 0.0641 \times 100=$ $16.07 \%$ of the given amount of fish food during the 30 days. Thus the 'house keeping' of $M$. vittatus in different salinities may be established. In 50 days, the necessary food will amount to $0.0641 \times 50=3.2050$ times the initial biomass, while the daily increment accumulates to yield $0.0641 \times 0.1607=$ 0.516 times the initial biomass.

Using the data in Table $I$, the specific growth rates of $M$. vittatus in different salinities have been calculated and are presented in Fig.2. From this it is evident that juveniles reared in fresh water displayed better growth than juveniles reared in higher salinities (6 and $10 \%$ ).

Table II represents the flesh production in $M$. vittatus reared at the tested salinity levels. One $\mathrm{kg}$ of juvenile fish each weighing about $1.640 \mathrm{~g}$ reared in fresh water requires $3.540 \mathrm{~kg}$ of Tubifex worm to produce $483 \mathrm{~g}$ newly synthesized flesh in 50 days, while when reared in a salinity of $10 \%, 1 \mathrm{~kg}$ of fish each weighing about $1.605 \mathrm{~g}$ requires $4.655 \mathrm{~kg}$ of Tubifex worm to produce $177 \mathrm{~g}$ newly synthesized flesh over the same time. Under an unrestricted feeding schedule, fed on the same food, the fish flesh production averaged $731 \mathrm{~g}$ (Aranuchalam, 1978b).

\section{Chemical analysis of food}

The average values obtained for water, ash and fat contents of Tubifex tubifex are given in Table III. The water content of worm amounted to $83.92 \%$ 


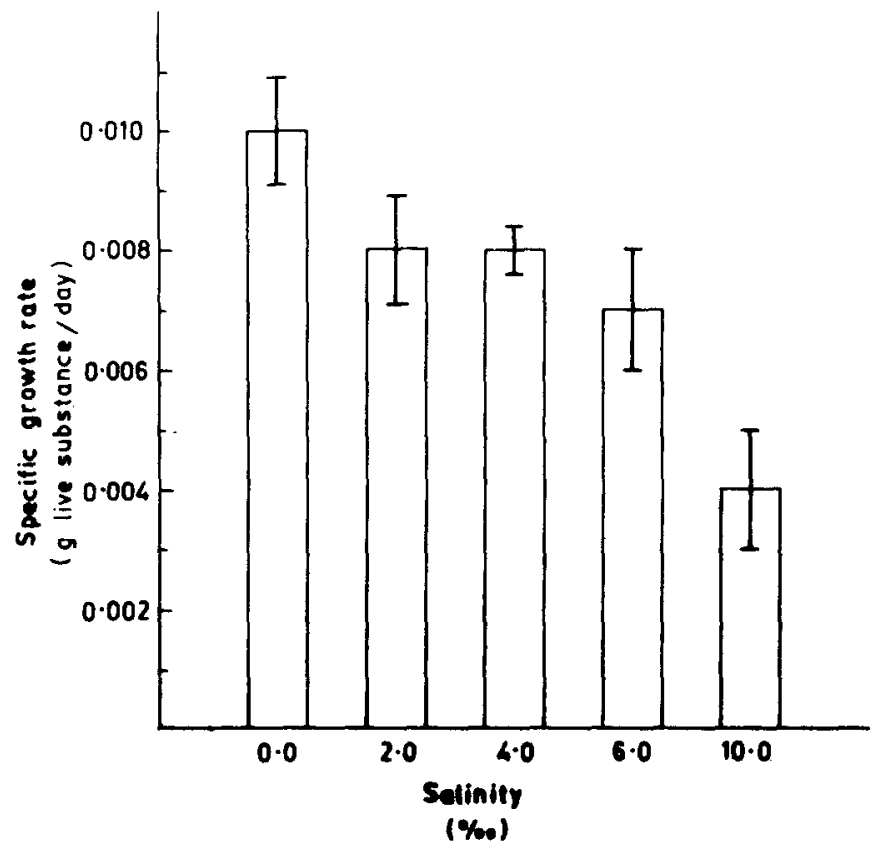

Fig. 2. Effect of salinity on the specific growth rate (g/day) of Mystus vittatus.

\section{TABLE II}

Effect of salinity on the fish flesh production in Mystus vittatus. Each value is the average performance of three individuals

\begin{tabular}{llll}
$\begin{array}{l}\text { Salinity } \\
(\%)\end{array}$ & $\begin{array}{l}\text { Initial biomass } \\
(\mathrm{g})\end{array}$ & $\begin{array}{l}\text { Food required by } 1 \mathrm{~kg} \\
\text { of fish in 50 days } \\
(\mathrm{kg})\end{array}$ & $\begin{array}{l}\text { Amount of flesh } \\
\text { produced by } 1 \mathrm{~kg} \text { of } \\
\text { fish in } 50 \text { days } \\
(\mathbf{k g})\end{array}$ \\
\hline 0 & 1.640 & 3.540 & 0.483 \\
2 & 1.660 & 3.520 & 0.397 \\
4 & 2.160 & 3.745 & 0.400 \\
6 & 1.645 & 4.455 & 0.367 \\
10 & 1.605 & 4.655 & 0.177 \\
\hline
\end{tabular}

of the living matter. The ash content was $4.31 \%$ and the fat content averaged $35.21 \%$. Since dry weight, ash and fat contents were estimated, the crude protein values could be calculated, and the value obtained was $60.48 \%$. In the literature, the water content values reported for Tubifex tubifex are 82\% (Ivlev, 1939), 84\% (Warren and Davis, 1967), 83.9\% (Pandian and Raghuraman, 1972) and 83.6/ (Katre and Reddy, 1979). Similarly, the ash content values reported in the literature are $4.0 \%$ (Raghuraman, 1973) and $4.2 \%$ (Katre and Reddy, 1979). 
The mean water, ash, fat and crude protein values of $M$. vittatus reared at different salinities are summarized in Table IV. Fish reared in a salinity of $0 \%$ contained $78.89 \%$ water and the value decreased with increase in salinity. The lowest water content $(75.47 \%$ ) was seen in fish reared in a salinity of $10 \%$. In contrast to this, ash content increased from $21.65 \%$ (fresh water) to $25.65 \%$ $(10 \%$ ). Fat content increased from $36.62 \%$ in fish reared in a salinity of $2 \%$ to $42.25 \%$ in individuals reared in $10 \%$, while fish reared in fresh water contained $39.33 \%$. The crude protein content was lowest (32.19\%) in individuals exposed to a salinity of $10 \%$.

\section{DISCUSSION}

The fish belonging to the genus Mystus have been recorded in fresh water and some are known to thrive in brackish waters (Pandian, 1970). Since there was heavy mortality of $M$. vittatus beyond a salinity of $10 \%$ (Arunachalam, $1978 \mathrm{a}$ ), the food conversion studies were done up to salinity of $10 \%$. Further, at $10 \%$, the food organisms (Tubifex tubifex) were found to disintegrate within $24 \mathrm{~h}$ and hence the feeding schedule was restricted to $4 \mathrm{~h} /$ day.

\section{TABLE III}

Chemical composition of Tubifex tubifex. Water content is expressed as a percentage of live weight; ash, fat and crude protein as a percentage of dry weight. Each value is the mean of five estimations

\begin{tabular}{ll}
\hline Constituents & Mean values \\
& $(\%)$ \\
\hline Water & $83.92 \pm 0.208$ \\
Ash & $4.31 \pm 1.215$ \\
Fat & $35.21 \pm 4.893$ \\
Crude protein & 60.48 \\
\hline
\end{tabular}

\section{TABLE IV}

Effect of salinity on the body composition of Mystus vittatus. Water content is given as a percentage of live weight; ash, fat and crude protein as percentages of dry weight. Each value is the mean of three estimations

\begin{tabular}{|c|c|c|c|c|}
\hline $\begin{array}{l}\text { Salinity } \\
(\%)\end{array}$ & $\begin{array}{l}\text { Water } \\
(\%)\end{array}$ & $\begin{array}{l}\text { Ash } \\
(\%)\end{array}$ & $\begin{array}{l}\text { Fat } \\
(\%)\end{array}$ & $\begin{array}{l}\text { Crude protein } \\
\text { (\%) }\end{array}$ \\
\hline 0 & $78.89 \pm 0.631$ & $21.65 \pm 0.764$ & $39.33 \pm 1.315$ & 39.02 \\
\hline 2 & $78.36 \pm 0.714$ & $20.47 \pm 1.106$ & $36.63 \pm 0.658$ & 42.91 \\
\hline 4 & $76.63 \pm 2.259$ & $20.11 \pm 0.524$ & $36.86 \pm 3.253$ & 43.03 \\
\hline 6 & $76.84 \pm 2.273$ & $20.04 \pm 1.792$ & $38.01 \pm 2.309$ & 41.95 \\
\hline 10 & $75.47 \pm 3.289$ & $25.56 \pm 2.683$ & $42.25 \pm 5.162$ & 32.19 \\
\hline
\end{tabular}


The IBP scheme of energy balance (Petrusewicz and McFadyen, 1970) for a fish is represented by the equation:

$C=P+R+F+U$

where

$C=$ food consumed,

$P=$ growth or production,

$R=$ energy loss as heat due to metabolism,

$F=$ undigested food,

$U=$ nitrogenous excretory products.

In fishes, absorption efficiency, which has a bearing on the $F$ value does not significantly vary as a function of body weight (Gerking, 1952; Pandian, 1967a), quantity of food (Pandian, 1967b) or temperature (Menzel, 1960; Hari Sethi, 1970). Therefore, any factor that alters either the $C$, the $P$ and/or the $R$ value is bound to influence the one which is not altered. The $C$ value of $M$. vittatus fed for a restricted period increased as a function of salinity from $17.84 \mathrm{mg}$ for fish in fresh water to $23.64 \mathrm{mg}$ for fish at a salinity of $10 \%$. Working on the fresh water catfish Heteropneustes fossilis, Reddy et al. (1976) have reported a higher intake of food at higher salinity. For example, the fish under an unrestricted feeding schedule was found to consume $142.3 \mathrm{mg}$ live worm/fish - day at a salinity of $7 \%$. Similarly, Raghuraman (1973) has also reported a higher intake of Tubifex worm in the euryplastic fish Tilapia mossambica at the highest salinity level $(27 \% 0)$. However, the present values cannot be compared with the values of Reddy et al. (1976), due to large size differences. In fresh water, under restricted feeding, $M$. vittatus consumed $17.84 \mathrm{mg}$ dry food/fish . day, while under an unrestricted feeding schedule, the fish consumed $32.58 \mathrm{mg}$ dry Tubifex/fish - day (Arunachalam, 1978b). The value of $P$ is also found to be affected by salinity in $M$. vittatus. The value of $P$ in the individuals decreased as a function of salinity. Niimi and Beamish (1974) have indicated that, in fishes, the net energy of the food is channeled to basal metabolism, growth and activity etc. In the present study, $M$. vittatus was found to be more active at high salinity and the apparent increased activity probably accelerated the feeding rate and the energy of the food was expended on osmotic regulation, and probably less energy was channeled for the growth process.

Although many workers have published analyses of the body composition of fish (see Love, 1970; Halver, 1972), few workers have attempted to examine the changes in body composition in relation to salinity (Katre, 1973; Raghuraman, 1973). Raghuraman (1973) observed that the body composition of Tilapia mossambica was greatly affected by salinity. A similar change in body composition in relation to salinity has been observed in $M$. vittatus. When salinity was increased, there was an immediate increase in fat content while water content decreased. Further, there was a corresponding decrease in crude protein. Working on Tilapia mossambica, Pandian and Raghuraman (1972) reported that changes in fat content are buffered by changes in crude protein. Thus it may be surmised that salinity influences the food conversion and body composition in $M$. vittatus. 


\section{ACKNOWLEDGEMENTS}

The authors express their appreciation to Dr Katre Shakuntala, Department of Zoology, Bangalore University for valuable suggestions and to Mr Nagendra, Research Scholar for help.

\section{REFERENCES}

Al Dahan, N.K. and Bhatti, M.N., 1977. Salinity tolerance of Gambusia affinis (Baird and Girard) and Heteropneustes fossilis (Bloch). J. Fish Biol., 11: 309-313.

Arunachalam, S., 1978a. Salinity stress on the swimming behaviour of a juvenile freshwater catfish Mystus vittatus (Bloch). Proc. 7 Annu. Conf. Ethol. Soc. India, Madras, No. VB 3/39: 28-29.

Arunachalam, S., 1978b. The Energetics of Feeding and Body Composition of a Freshwater Catfish Mystus vittatus. M. Phil dissertation, Bangalore University, Bangalore, $57 \mathrm{pp}$.

Association of Official Agricultural Chemists, 1950. Methods of Analyses. Association of Official Agricultural Chemists, Washington, D.C.

Brockson, R.W. and Cole, R.E., 1972. Physiological responses of three species of fishes to various salinities. J. Fish. Res. Board Can., 29: 399-405.

Canagaratnam, P., 1959. Growth of fishes in different salinities. J. Fish. Res. Board Can., 16: $121-130$.

De Silva, S.S. and Perera, P.A.B., 1976. Studies on the young mullet, Mugil cephalus L. I: Effects of salinity on food intake, growth and food conversion. Aquaculture, $7: 327-338$

Gerking, S.D., 1952. The protein metabolism of the sunfishes of different ages. Physiol. Zool., 25: 358-372.

Haffef, M.A. and Qasim, S.Z., 1960. The food and feeding habits of Mystus vittatus (Bloch). Proc. Indian Sci. Congr., 47(3): 460 pp.

Halver, J.E., 1972. Fish Nutrition. Academic Press, London, 713 pp.

Hari Sethi, S., 1970. Temperature and Bioenergetics of Cichlasoma bimaculatum. Ph. D. thesis, Oregon University.

Hettler, W.F., 1976. Influence of temperature and salinity on routine metabolic rate and growth of young Atlantic menhaden. J. Fish. Biol., 8: 55-65.

Ivlev, V.S., 1939. Transformation of energy by aquatic animals: coefficient of energy consumption by Tubifex tubifex (Oligochaete). Int. Rev. Ges. Hydrobiol. Hydrogr., 38: $449-458$.

Katre, S., 1973. Ecophysiological Studies on Growth and Reproduction of some Thermoconformers. Ph. D. thesis, Bangalore University, Bangalore, $143 \mathrm{pp}$.

Katre, S. and Reddy, S.R., 1979. Influence of temperature-salinity combinations on the food intake, growth and conversion efficiency of Gambusia affinis (Pisces). Pol. Arch. Hydrobiol. (in press).

Kinne, O., 1962. Irreversible non-genetic adaptation. Comp. Biol. Physiol., 5: 265-282.

Kosi Onodera, 1962. Some Data on Eel-culture in Japan. Indo-Pac. Fish. Counc., Occasional Pap., 62/6, 4 pp.

Love, M.R., 1970. The Chemical Biology of Fishes. Academic Press, London, 547 pp.

Menzel, D.W., 1960. Utilization of food by a Bermuda reef fish, Epinephelus guttatus. J. Cons. Perms. Int. Explor. Mer., 25: 216-222.

Moitra, 1956. Quantitative studies on the food of some carnivorous fishes of Uttar Pradesh. Proc. Indian Sci. Congr., 43: 307.

Muddanna, V., 1971. Freshwater Fishes of Mysore State. Their Vernacular Name, Distribution, Growth, Feeding and Fishery. Univ. Agric. Sci., Hebbal, Bangalore, 52 pp. 
Niimi, A.J. and Beamish, F.W.H., 1974. Bioenergetics and growth of large mouth bass (Micropterus salmoides) in relation to body weight and temperature. Can. J. Zool., 52: $447-456$.

Otto, R.G., 1971. Effects of salinity on the survival and growth of pre-molt Coho salmon (Oncorhynchus kisutch). J. Fish. Res. Bourd Canada, 28: 343-349.

Paine, R.T., 1964. Ash and calorie determinations of sponges and Ophisthobranchs tissues. Ecology, 45: 384-387.

Pandian, T.J., 1967a. Intake, digestion, absorption and conversion of food in the fishes Megalops cyprinoides and Ophicephalus striatus. Mar. Biol, 1: 16-32.

Pandian, T.J., 1967b. Transformation of food in the fish Megalops cyprinoides. 1. Influence of quantity of food. Mar. Biol., 1: 107-109.

Pandian, T.J., 1970. Feeding and reproductive cycles of the fish Mystus gulio in the Cooum backwaters. Madras. Indian J. Fish., 13(1): 322-333.

Pandian, T.J. and Raghuraman, R., 1972. Effects of feeding rate on conversion efficiency and chemical composition of the fish Tilapia mossambica. Mar. Biol., 12: 129-136.

Petrusewicz, K. and McFadyen, A., 1970. Productivity of Terrestrial Animals. IBP Handbook No. 13. Blackwell, Oxford, $190 \mathrm{pp}$.

Qayyarn, A. and Qasim, S.Z., 1961. The Pecundity of Ophicephalus punctatus (Bloch), Mystus vittatus (Bloch) and Callichrous pabda (Ham.). Proc. Indian Sci. Congr., 48(3): $430-431$.

Raghuraman, R., 1973. Studies on food intake, and utilisation in some fishes. Ph.D. thesis, Bangalore University, Bangalore, $114 \mathrm{pp}$.

Reddy, S.R., Katre, S. and Srinivasachar, H.R., 1976. Effects of different ration levels on the food conversion of Heteropneustes fossilis (Bloch). Symposium on Modern Trends in Zoological Research, University of Calcutta, pp. 40-41.

Warren, C.E. and Davis, G.E., 1967. Laboratory studies on the feeding, bioenergetics and growth of fish. In: S.D. Gerking (Editor), The Biological Basis of Freshwater Fish Production. Blackwell, Oxford, pp. 195-214. 